DOI: https://doi.org/10.24127/ajpm.v8i1.1628

\title{
PENGEMBANGAN INSTRUMEN TES PILIHAN GANDA UNTUK MENGUKUR TINGKAT KEMAMPUAN BERPIKIR MATEMATIKA SISWA SMA
}

\author{
Rolina Amriyanti Ferita ${ }^{1}$, Mia Fitria ${ }^{2}$ \\ ${ }^{1,2}$ Pendidikan Matematika, Universitas Nahdlatul Ulama Kalimantan Selatan \\ E-mail: $\frac{\text { rolinaamariyantiferita@gmail.com }}{\text { miafitria87@gmail.com }{ }^{2}}$
}

Received 21 November 2018, Received in revised form 24 January 2019; Accepted 2 May 2018

\begin{abstract}
This research is development research that aims to develop multiple-choice test questions. The desired test question is valid, reliable with a good level of difficulty, good distinguishing power, and troublemaker that serves to measure the thinking skills of high school students in mathematics. This research was carried out by procedure 1) determining the purpose of the test, 2) making a test box, 3) conducting a review and revision based on the advice of the material and evaluation experts, 4) conducting a trial, and 5) conducting an item analysis. Results of analysis produce four questions is invalid, the value of $r=0.844$ to $r$ table 0.4438 which means reliable test questions, there are two questions that are not good or difficult, there are two questions that no distinguishing features are good, there are three questions that distractor does not function and there is one question that is omitted so that each thinking skill has the same number of questions based on the calculated $r$ so that 12 multiple-choices test questions are valid, reliable, have a good level of difficulty and good distinguishing power, and functioning distractors. The results of the measurement of students 'thinking skills obtained that students' thinking skills were still at a low level.
\end{abstract}

Keywords: Multiple-Choice Test Questions; thinking skills.

\section{PENDAHULUAN}

Dahulu menurut Subondo matematika hanya menitik beratkan pada ilmu hitung dan cara berhitung saja. Ditambahkan lagi menurut Ruseffendi matematika dulu lebih kepada menghafal, keterampilan berhitung, keterampilan otak lebih diutamakan daripada kegunaan, urutan dalam operasi pun harus diterima tanpa alasan (Alhaddad, 2015). Padahal hakikat belajar matematika menurut Hudoyo merupakan kegiatan mental yang tinggi dimana melibatkan ide-ide, struktur-struktur dan hubunganhubungan yang disusun secara hierarki dengan alasan yang logis (Hasratuddin, 2013). Dengan kata lain matematika melibatkan konsep-konsep abstrak dalam menemukan dan mengembangkan

kebenaran

berdasarkan alasan yang logis.

Karena berkenaan dengan konsepkonsep abstrak dalam menemukan kebenaran, pembelajaran matematika menuntut siswa untuk mempunyai keterampilan berpikir yang baik. Menurut Purwadhi bahwa proses dasar berpikir digunakan untuk memilih yang terbaik di antara beberapa pilihan dalam mengambil keputusan (U.S, 2015). Oleh sebab itu dalam setiap menyelesaikan masalah tidak hanya tentang mendapatkan hasil yang benar tapi hasil yang juga bisa dipertanggungjawabkan secara logis termasuk proses dalam menemukan jawaban tersebut. Keterampilan berpikir siswa juga mempunyai peranan dalam proses mengonstruksi ide-ide baru dari konsep- 
konsep yang sudah ada sebelumnya dan hal-hal yang baru diperoleh siswa. Sehingga dengan keterampilan berpikir yang baik siswa dapat memecahkan masalah dalam kehidupan sehari-hari.

Keterampilan berpikir pada ranah kognitif yang dirumuskan awal oleh Benjamin Bloom terdiri dari pengetahuan, pemahaman, penerapan, analisis, sintesis dan evaluasi. Kemudian keterampilan berpikir yang awalnya adalah pasif dimodifikasi oleh Krathwohl dan Anderson menjadi kata kerja aktif yaitu mengetahui, memahami, mengaplikasikan, menganalisis, mengevaluasi dan mencipta (Wicasari \& Ernaningsih, 2016). Keterampilan berpikir tersebut kemudian dinamakan taksonomi Bloom. Keterampilan berpikir mempunyai dua tingkatan yaitu rendah dan tinggi. Keterampilan tingkat tinggi (Higher Order Thinking Skills) meliputi keterampilan menganalisis, mengevaluasi dan mencipta sedangkan tingkat rendah (Lower Order Thinking Skills) meliputi mengetahui, memahami dan mengaplikasikan.

Peningkatan keterampilan berpikir siswa sekarang menjadi perhatian bagi pemerintah. Hal ini dapat dilihat dengan diterapkannya kurikulum 2013. Kurikulum 2013 adalah kurikulum yang ditetapkan oleh pemerintah untuk menyempurnakan kurikulum sebelumnya yaitu Kurikulum KBK tahun 2004 dan KTSP tahun 2006. Penyempurnaan kurikulum ini melibatkan pendekatan yang berbasis kompetensi dan karakter (Sulaeman, 2015). Kurikulum 2013 yang diberlakukan sejak tahun ajaran 2013/2014 ini mempunyai tujuan yaitu mewujudkan insan Indonesia yang memiliki kompetensi sikap, pengetahuan, dan keterampilan sehingga mereka dapat menjadi pribadi dan warga negara yang produktif, kreatif, inovatif, dan afektif dan mampu berkontribusi dalam kehidupan bermasyarakat, berbangsa, bernegara serta dalam kehidupan peradaban dunia (Halimah, 2014). Hal ini selaras dengan tujuan pendidikan nasional dalam Undang-undang Sistem Pendidikan Nasional No. 20 Tahun 2003 Pasal 3 yaitu untuk mengembangkan potensi peserta didik agar menjadi manusia yang beriman, bertaqwa kepada Tuhan Yang Maha Esa, berakhlak mulia, sehat, berilmu, cakap, kreatif, mandiri dan menjadi warga negara yang demokratis serta bertanggung jawab.

Keterampilan berpikir tingkat tinggi siswa menjadi fokus dalam kurikulum 2013. Keterampilan berpikir tingkat tinggi siswa terletak pada proses pembelajaran. Karena pada proses pembelajaran terdapat interaksi antara siswa yang belajar dengan guru yang mengajar matematika. Hal ini juga didukung oleh Van De Walle bahwa pemahaman dan keterampilan paling baik dikembangkan ketika siswa diizinkan untuk bergulat dengan ide-ide baru, membuat dan mempertahankan penyelesaian soal dan berpartisipasi di dalam komunitas pelajar matematika (Hidayati, 2017). Oleh sebab itu dorongan dari guru diperlukan untuk membuat siswa memiliki rasa ingin tahu yang tinggi dan bisa mengembangkan pemahamannya sendiri.

Pada awal penerapannya, siswa mulai diperkenalkan dengan soal-soal HOTS. Akan tetapi siswa mengalami kesulitan dalam menyelesaikan soalsoal HOTS karena sejak dulu siswa sudah terbiasa dengan soal-soal LOTS yang hanya mengandalkan kemampuan untuk me-recall. Tidak hanya itu, terkadang guru pun masih mengalami kendala dalam pelaksanaan kurikulum 2013 pada proses pembelajaran misalnya dalam memotivasi siswa untuk 
lebih aktif dan membangkitkan rasa ingin tahu siswanya. Sehingga sampai sekarang masih ada guru yang menggunakan soal-soal rutin dalam melakukan evaluasi dan pembelajaran di kelas. Padahal sebelum diterapkannya kurikulum 2013, pemerintah sudah membekali guru-guru dengan pelatihan atau workshop tentang penerapan kurikulum 2013. Bahkan pemerintah juga menyediakan Buku Sekolah Elektronik (BSE) sebagai sumber belajar yang dapat diakses dengan mudah dan gratis. Meskipun masih ada guru yang memakai sumber belajar lain selain yang dibuat oleh pemerintah dan sumber belajar tersebut masih memuat soal-soal rutin yang lebih banyak. Melihat perkembangan pasca diterapkannya kurikulum 2013, maka pada penilitian yang dilakukan ingin melihat bagaimana keterampilan berpikir siswa setelah diterapkannya kurikulum 2013. Untuk mendapatkan gambaran tentang keterampilan berpikir siswa khususnya siswa sekolah menengah atas, maka dikembangkanlah perangkat soal tes.

Pada penelitian yang dilakukan oleh Kurniason dkk (2018) terhadap 36 siswa di SMA Negeri 1 Pontianak pada mata pelajaran Matematika diperoleh kesimpulan bahwa keterampilan berpikir tingkat tinggi berada pada kriteria cukup. Sedangkan pada penelitian yang dilakukan oleh Saido dkk (2015) terhadap 418 siswa kelas 7 di wilayah Kurdistan pada mata pelajaran Sains diperoleh kesimpulan bahwa keterampilan berpikir siswa masih berada pada tingkatan rendah terutama pada tingkat sintesis dan evaluasi. Ada dua hal yang menjadi faktor penyebab keterampilan berpikir siswa masih berada pada tingkat rendah yaitu pertama kurikulum sains yang memberikan siswa kemampuan untuk mengerti sepenuhnya bagaimana sains sebagai fungsi disiplin yang dapat membantu siswa untuk berpikir pada tingkat yang lebih tinggi dan kedua lingkungan pembelajaran.

Perbedaan kedua penelitian itu terletak pada instrument yang digunakan. Pada penelitian Kurniason dkk instrumen yang digunakan berupa soal tes uraian yang terdiri dari 6 soal dengan 1 soal mewakili satu keterampilan berpikir. Hal ini dikarenakan sampel penelitian ini hanya satu kelas dengan jumlah siswa 36 di SMAN 1 Pontianak sehingga langkahlangkah siswa menjawab soal dapat terlihat dengan jelas sehingga analisis yang dilakukan oleh peneliti lebih rinci. Sedangkan instrumen yang digunakan pada penelitian Saido dkk adalah pilihan ganda yang terdiri dari 20 soal karena pada penelitian ini melibatkan jumlah sampel yang besar pada suatu wilayah sehingga analisis soal dapat dilakukan dengan mudah dan cepat.

Berdasarkan kedua penelitian tersebut, maka perangkat soal tes yang dikembangkan pada penelitian ini adalah soal tes pilihan ganda karena jumlah sampel yang diambil berjumlah besar yang berasal dari beberapa sekolah menengah atas di kota Banjarmasin. Pemilihan soal tes pilihan ganda juga dikarenakan soal tes tersebut mempunyai opsi jawaban lebih dari satu sebagai pengecoh sehingga menurut (Fanani, 2018) siswa yang tidak menguasai materi dan menjawab asalasalan akan terkecoh dengan pilihan jawaban yang salah. Pada soal pilihan ganda, jawaban yang benar diberi poin 1 dan salah poin 0 . Sehingga pada proses pemeriksaannya, tes pilihan ganda tidak memerlukan waktu yang lama meskipun dalam pembuatannya membutuhkan waktu yang tidak sebentar dan cenderung lebih sulit dari pada soal tes non-objektif. Perangkat tes yang baik digunakan sebagai alat 
ukur haruslah valid dan reliable. Untuk pembuatan soal tes pilihan ganda didukung juga dengan tingkat kesukaran yang baik, daya pembeda yang baik dan berfungsinya distraktor pada setiap butir soal. Sehingga hasil pengukuran dapat dapat memberikan gambaran tentang keterampilan berpikir siswa.

Tujuan dari penelitian ini adalah mengembangkan soal tes pilihan ganda yang valid, reliable, tingkat kesukaran yang baik, daya pembeda yang baik dan berfungsinya distraktor pada setiap butir soal untuk mengukur tingkat keterampilan berpikir siswa SMA di kota Banjarmasin.

\section{METODE PENELITIAN}

Penelitian ini adalah penelitian pengembangan dengan prosedurnya mengacu pada langkah-langkah penyusunan item-item soal menurut Kartowagiran (2012) yaitu 1) menentukan tujuan dilakukannya tes, 2) membuat kisi-kisi dari soal tes, 3) melakukan review dan perbaikan soal berdasarkan saran para ahli yaitu ahli materi dan ahli evaluasi, 4) melakukan uji coba soal dan 5) analisis butir soal.

Materi yang dibuat soal pada penelitian ini adalah materi matematika kelas $\mathrm{X}$ yaitu trigonometri. Uji coba dilakukan pada siswa SMA Negeri kelas X. Sampel uji coba tahap awal sebanyak 31 orang siswa yang diambil secara acak dari beberapa sekolah di kota Banjarmasin. Soal tes adalah bentuk pilihan ganda. Tingkat keterampilan berpikir yang digunakan dalam pembuatan soal ini mengacu pada taksonomi Bloom yaitu mengetahui (C1), memahami (C2), mengaplikasikan (C3), menganalisis (C4), mengevaluasi (C5) dan mencipta (C6). Masing-masing tingkat kemampuan berpikir mempunyai jumlah soal 4 butir dengan urutan soal dari tingkat terendah yaitu memahami sampai tingkat tertinggi yaitu mencipta. Total seluruh soal yang dibuat pada penelitian ini adalah 24 butir soal.

Uji coba perangkat soal yang telah dianalisis dan layak untuk digunakan dalam pengambilan data dilakukan dengan jumlah sampel yang besar yaitu 403 orang. Jumlah sekolah yang menjadi tempat pengambilan sampel lebih banyak dari uji coba pertama.

Analisis soal yang dilakukan pada perangkat soal pilihan ganda ini adalah uji validitas item soal, reliabilitas, analisis tingkat kesukaran, analisis daya pembeda dan analisis distraktor. Soal yang baik adalah soal yang memenuhi semua persyaratan pada analisis tersebut. Soal yang tidak memenuhi akan dibuang. Jumlah akhir hasil analisis soal tetap menghasilkan jumlah yang sama untuk setiap tingkat keterampilan berpikir pada taksonomi Bloom.

Menurut Azwar (Kartowagiran, 2012) suatu tes mempunyai validitas tinggi jika tes tersebut memberikan hasil pengukuran yang tepat sesuai dengan maksud dari soal tes tersebut dibuat. Validitas dari soal tes pada penelitian dimaksudkan untuk melihat bahwa soal tes yang dibuat layak digunakan sebagai alat ukur kemampuan HOTS siswa SMA Negeri kelas X. Uji validitas dilakukan dengan menggunakan bantuan aplikasi SPSS versi 22 dan menggunakan korelasi pearson. Pengujian dilakukan dengan mengorelasikan antara skor setiap item soal dengan skor total. Item soal yang valid ditunjukkan dengan nilai derajat signifikansinya kurang dari 0.05 .

Reliabilitas menurut Masidjo
adalah kemampuan tes untuk memperlihatkan konsistensi dari hasil pengukurannya yang diperlihatkan dalam hasil yang tepat dan teliti (Amelia, 2016). Alat ukur dikatakan 
DOI: https://doi.org/10.24127/ajpm.v8i1.1628

reliable menurut Lawrence (Kartowagiran, 2012) adalah alat ukur yang menghasilkan hasil yang stabil. Artinya alat ukur dapat digunakan dalam mengukur suatu yang sama dengan waktu yang berbeda tetapi menghasilkan hasil yang sama atau hampir sama. Reliabilitas pada penelitian ini ingin melihat bagaimana keterpakaian soal dalam mengukur kemampuan HOTS siswa dalam waktu yang berbeda tetapi menghasilkan hasil yang stabil. Perhitungan estimasi dari reabilitas soal dilakukan dengan menggunakan bantuan aplikasi SPSS versi 22. Model yang digunakan adalah Alpha. Soal tes dikatakan reliable jika nilai Cronbach's Alpha lebih dari $r$ table. Nilai $r$ table ditentukan dengan derajat bebas yaitu n-2 dengan $\mathrm{n}$ adalah jumlah soal tes dan signifikansi 0.05.

Menurut Thomas dan Dawton (Kartowagiran, 2012) item soal yang memiliki tingkat kesukaran berada pada nilai 0,25 - 0,75 maka sudah dikatakan baik. Semakin mendekati 0 maka item soal dikatakan sulit dan jika mendekati 1 maka soal dikatakan mudah. Adapun formula yang digunakan untuk menghitung tingkat kesukaran item soal menurut Kartowagiran (2012) adalah sebagai berikut:

$$
P_{i}=\frac{n}{N}
$$

dengan

$P_{i}=$ tingkat kesukaran item soal ke $i$

$i=$ nomor item soal

$n$ = jumlah siswa yang menjawab benar

$N=$ jumlah siswa yang menjawab

Daya pembeda menurut Kusaeri dan Suprananto dalam Amelia (2016) adalah kemampuan item atau butir soal untuk membedakan siswa yang menguasai materi dengan siswa yang tidak menguasai materi yang diujikan. Dalam penelitian ini daya pembeda dianalisis dengan menggunakan metode korelasi point biserial. Menurut Kartowagiran (2012) koefisien point biserial merupakan kombinasi antara skor item soal, skor total dan tingkat kesukaran. Formula yang digunakan dalam menganalisis daya pembeda menurut Crocker dan Algina (Kartowagiran, 2012) adalah

$$
\rho_{\text {bis }}=\frac{\mu_{+}-\mu_{X}}{\sigma_{X}} \sqrt{\frac{p}{q}}
$$

Dengan:

$\rho_{\text {bis }}=$ korelasi point biserial

$\mu_{+}=$rata-rata skor siswa yang

menjawab benar item soal

$\mu_{X}=$ rata-rata skor total

$\sigma_{X}=$ standar deviasi skor total

$p=$ proporsi siswa menjawab benar

$q=1-p$

Interpretasi dari hasil perhitungan koefisien point biserial menurut Ebel dalam (Kartowagiran, 2012) adalah suatu butir soal dikatakan baik jika korelasi point biserialnya minimal 0,41 .

Distraktor menurut Purwanto (Amelia, 2016) adalah pilihan pada soal pilihan ganda yang bukan kunci jawaban. Analisis dari keberfungsian distraktor mengacu kepada pendapat Nitko (Kartowagiran, 2012) bahwa distraktor dikatakan berfungsi jika dipilih minimal satu orang dari kelompok siswa berkemampuan rendah. Kemampuan akademik siswa dikategorikan menjadi tiga yaitu tinggi, sedang dan rendah berdasarkan skor total yang diperoleh. Setiap level kemampuan dibagi sama rata kecuali untuk level sedang dengan jumlah 11 orang siswa.

Analisis soal uji coba untuk memperoleh hasil tentang tingkat keterampilan berpikir siswa menggunakan SPSS versi 22. Hasil perhitungan yang dipakai adalah rerata 
(mean), standar deviasi, jangkauan (range), dan median. Sebelum itu perlu ditentukan terlebih dahulu apakah data berdistribusi normal atau tidak dengan menghitung nilai kecondongan (skewness) dan keruncingan (kurtosis). Menurut Hair bahwa jika nilai z untuk kecondongan dan keruncingan terletak di antara $\pm 1,96$ dengan derajat signifikansi 0,05. Dengan kata lain, nilai kecondongan dan keruncingan yang berada di antara \pm 1 menunjukkan data berdistribusi normal (Saido, Siraj, Nordin, \& Al-Amedy, 2015).

\section{HASIL PENELITIAN DAN PEMBAHASAN}

Hasil perhitungan untuk uji validitas item dari 24 soal dapat dilihat pada Tabel 1.

Tabel 1. Hasil Uji Validitas Item

\begin{tabular}{crcrcrcr}
\hline $\begin{array}{c}\text { Nomor } \\
\text { Soal }\end{array}$ & Sig. & $\begin{array}{c}\text { Nomor } \\
\text { Soal }\end{array}$ & Sig. & $\begin{array}{c}\text { Nomor } \\
\text { Soal }\end{array}$ & $\begin{array}{c}\text { Sig. } \\
\text { Nomor }\end{array}$ & Sig. \\
Soal & \\
\hline 1 & 0.002 & 7 & 0.221 & 13 & 0.624 & 19 & 0.003 \\
2 & 0.386 & 8 & 0.002 & 14 & 0 & 20 & 0 \\
3 & 0.024 & 9 & 0 & 15 & 0 & 21 & 0.001 \\
4 & 0 & 10 & 0.003 & 16 & 0 & 22 & 0 \\
5 & 0.044 & 11 & 0.006 & 17 & 0.031 & 23 & 0 \\
6 & 0.001 & 12 & 0 & 18 & 0 & 24 & 0.346 \\
\hline
\end{tabular}

Dari Tabel 1 dapat dilihat bahwa ada empat soal yang nilai derajat signifikansinya lebih dari 0,05 yaitu soal nomor $2,7,13$, dan 24 . Karena soalsoal tersebut lebih dari 0,05 maka keempat soal tersebut tidak valid sedangkan 20 soal yang lain nilai derajatnya signifikansinya kurang dari 0,05 yaitu $1,3,4,5,6,8,9,10,11,12$, $14,15,16,17,18,19,20,21,22$ dan 23 yang berarti soal-soal tersebut valid. Soal-soal yang tidak valid dibuang sehingga soal yang tersisa berjumlah 20 soal untuk menentukan reliabilitas soal selanjutnya. perhitungan estimasi reliabilitas dari 20 soal yang tersisa menghasilkan nilai Cronbach's Alpha sebesar 0.844 . Dengan derajat bebas 18 dan $\alpha=0,05$ maka diperoleh $\mathrm{r}$ tabel sebesar 0,4438. Ini berarti nilai pada kolom Cronbach's Alpha lebih besar daripada $\mathrm{r}$ tabel sehingga dapat disimpulkan bahwa soal tes yang dibuat reliable artinya soal dapat digunakan untuk mengukur kemampuan HOTS siswa meskipun dalam waktu yang berbeda.

Hasil analisis tingkat kesukaran pada soal tes dapat dilihat pada Tabel 2.

Tabel 2. Hasil Analisis Tingkat Kesukaran

\begin{tabular}{cccccc}
\hline $\begin{array}{c}\text { Nomor } \\
\text { Soal }\end{array}$ & $\begin{array}{c}\text { Jumlah Siswa yang } \\
\text { Menjawab Benar }\end{array}$ & $\boldsymbol{P}_{\boldsymbol{i}}$ & $\begin{array}{c}\text { Nomor } \\
\text { Soal }\end{array}$ & $\begin{array}{c}\text { Jumlah Siswa yang } \\
\text { Menjawab Benar }\end{array}$ & $\boldsymbol{P}_{\boldsymbol{i}}$ \\
\hline 1 & 22 & 0.709677 & 14 & 18 & 0.580645 \\
3 & 23 & 0.741935 & 15 & 12 & 0.387097 \\
4 & 16 & 0.516129 & 16 & 12 & 0.387097 \\
5 & 13 & 0.419355 & 17 & 5 & 0.16129 \\
6 & 22 & 0.709677 & 18 & 22 & 0.709677 \\
8 & 20 & 0.645161 & 19 & 4 & 0.129032 \\
\hline
\end{tabular}


DOI: https://doi.org/10.24127/ajpm.v8i1.1628

\begin{tabular}{cccccc}
\hline $\begin{array}{c}\text { Nomor } \\
\text { Soal }\end{array}$ & $\begin{array}{c}\text { Jumlah Siswa yang } \\
\text { Menjawab Benar }\end{array}$ & $\boldsymbol{P}_{\boldsymbol{i}}$ & $\begin{array}{c}\text { Nomor } \\
\text { Soal }\end{array}$ & $\begin{array}{c}\text { Jumlah Siswa yang } \\
\text { Menjawab Benar }\end{array}$ & $\boldsymbol{P}_{\boldsymbol{i}}$ \\
\hline 9 & 8 & 0.258065 & 20 & 18 & 0.580645 \\
10 & 22 & 0.709677 & 21 & 15 & 0.483871 \\
11 & 9 & 0.290323 & 22 & 16 & 0.516129 \\
12 & 18 & 0.580645 & 23 & 18 & 0.580645 \\
\hline
\end{tabular}

Berdasarkan Tabel 2 diperoleh soal nomor 17 dan 19 memperoleh tingkat kesukaran yang kurang dari 0,25 sehingga dapat dikatakan kedua soal tersebut mempunyai tingkat kesukaran yang tidak baik atau sulit. Sedangkan untuk 18 soal yang lain yaitu 1, 3, 4, 5, $6,8,9,10,11,12,14,15,16,18,20$, 21, 22 dan 23 diperoleh nilai tingkat kesukaran yang masih berada pada interval $0,25-0,75$ sehingga dapat dikatakan 18 soal tersebut mempunyai tingat kesukaran yang baik. Soal nomor 17 dan 19 yang mempunyai tingkat kesukaran tidak baik atau bias dikatakan sulit dibuang sehingga jumlah soal yang tersisa sebanyak 18 soal untuk selanjutnya dilakukan analisis daya pembeda.

Hasil perhitungan dari analisis daya pembeda dapat dilihat pada Tabel 3.

Tabel 3. Hasil Perhitungan Analisis Daya Pembeda

\begin{tabular}{cccccc}
\hline Nomor Soal & $\boldsymbol{\rho}_{\boldsymbol{b i s}}$ & Nomor Soal & $\boldsymbol{\rho}_{\boldsymbol{b i s}}$ & Nomor soal & $\boldsymbol{\rho}_{\text {bis }}$ \\
\hline 1 & 0.515 & 9 & 0.683 & 16 & 0.634 \\
3 & 0.396 & 10 & 0.502 & 18 & 0.582 \\
4 & 0.6383 & 11 & 0.447 & 20 & 0.65 \\
5 & 0.358 & 12 & 0.589 & 21 & 0.564 \\
6 & 0.542 & 14 & 0.798 & 22 & 0.772 \\
8 & 0.535 & 15 & 0.622 & 23 & 0.712 \\
\hline
\end{tabular}

Berdasarkan Tabel 3 dapat dilihat bahwa ada dua soal yang mempunyai $\rho_{b i s}$ yang kurang dari 0,41 yaitu soal nomor 3 dan 5 ini berarti kedua soal ini tidak mempunyai daya pembeda yang baik. Sedangkan untuk 16 soal yaitu $1,4,6,8,9,10,11,12,14$, $15,16,18,20,21,22$ dan 23 mempunyai $\rho_{\text {bis }}$ yang lebih dari 0,41 ini berarti keenambelas soal ini mempunyai daya pembeda yang baik. 16 soal dapat digunakan untuk melihat mana siswa yang menguasai materi dana mana yang tidak menguasai materi. Dua soal yang tidak mempunyai daya pembeda yang baik dibuang sehingga soal yang tersisa berjumlah 16 soal untuk selanjutnya dilakukan analisis distraktor.

Hasil perhitungan dari analisis distraktor pada setiap soal dapat dilihat pada Tabel 4.

Tabel 4. Hasil Analisis Distraktor

\begin{tabular}{|c|c|c|c|c|c|}
\hline Nomor soal & $\mathbf{A}$ & B & $\mathbf{C}$ & D & $\mathbf{E}$ \\
\hline 1 & & 1 & 4 & 1 & 1 \\
\hline 4 & 1 & 4 & & 1 & 1 \\
\hline 6 & & 1 & 1 & 2 & 2 \\
\hline 8 & 1 & 1 & & 2 & 1 \\
\hline
\end{tabular}


DOI: https://doi.org/10.24127/ajpm.v8i1.1628

\begin{tabular}{ccccccc}
\hline Nomor soal & A & B & C & D & E \\
\hline 9 & 2 & 4 & 3 & 1 & \\
10 & 2 & 1 & 1 & & \\
11 & 2 & 4 & 2 & 2 & \\
12 & 0 & & 3 & 1 & 3 \\
14 & 1 & 1 & 0 & 7 & \\
15 & 4 & 3 & & 1 & 1 \\
16 & 1 & 5 & 2 & & \\
18 & 2 & 2 & 1 & 2 & \\
20 & 1 & 4 & & 2 & 2 \\
21 & 2 & 3 & & 1 & 1 \\
22 & 2 & 1 & 4 & & \\
23 & 1 & 3 & & 0 & 3 \\
\hline
\end{tabular}

Berdasarkan Tabel 4 dapat dilihat ada tiga soal yaitu soal nomor 12,14 , dan 23 yang distraktornya tidak dipilih oleh siswa kemampuan rendah ini berarti bahwa ketiga soal tersebut distraktornya yang tidak berfungsi. Sedangkan 13 soal yang lain yaitu soal nomor 1, 4, 6, 8, 9, $10,11,15,16,18,20,21$ dan 22 semua distraktornya dipilih oleh minimal satu orang siswa kemampuan rendah yang berarti ketigabelas soal tersebut semua distraktornya berfungsi. Tiga soal yang distraktornya tidak berfungsi dibuang sehingga soal yang tersisa berjumlah 13 . Jumlah tingkat keterampilan berpikir yang mengacu pada taksonomi Bloom ada enam yaitu mengetahui, memahami, mengaplikasikan, menganalisis, mengevaluasi dan mencipta maka jumlah keseluruhan seharusnya berjumlah kelipatan 6 dengan masing-masing tingkat mempunyai porsi yang sama. Berdasarkan hasil analisis soal dapat diperoleh 13 soal yang valid, reliable, mempunyai tingkat kesukaran yang baik, daya pembeda yang baik dan semua distraktornya berfungsi. Setelah dilihat kembali ada satu tingkat keterampilan berpikir yang mempunyai porsi soal lebih banyak dari pada tingkat yang lain yaitu pada tingkat mengaplikasikan. Soal-soal pada tingkat tersebut adalah soal nomor 9,10, dan 11 . Jika dilihat dari perhitungan reliabilitas, soal nomor 9 dihilangkan menghasilkan nilai pada kolom Cronbach's Alpha 0,853, nomor 10 dihilangkan menghasilkan nilai pada kolom Cronbach's Alpha 0,861, dan nomor 11 dihilangkan menghasilkan nilai pada kolom Cronbach's Alpha 0,869. Sehingga berdasarkan hasil estimasi reliabilitas tersebut maka soal nomor 11 dibuang. Jadi soal yang valid, reliable, mempunyai tingkat kesukaran yang baik, daya pembeda yang baik dan semua distraktornya berfungsi adalah soal nomor $1,4,6,8,9,10,15,16,18$, 20, 21, dan 22 .

Instrumen yang sudah valid, reliabel, tingkat kesukaran yang baik, daya pembeda yang baik dan berfungsinya distraktor pada setiap butir soal kemudian digunakan untuk pengambilan data hasil pengukuran. Adapun hasil yang diperoleh secara umum dapat dilihat pada Tabel 5 dan 6 . 
DOI: https://doi.org/10.24127/ajpm.v8i1.1628

Tabel 5. Statistik Deskriptif Keterampilan Berpikir Siswa

\begin{tabular}{lllll}
\hline Tingkat & $\begin{array}{l}\text { Rata- } \\
\text { rata }\end{array}$ & Variansi & Skewness & Kurtosis \\
& 1.4020 & 0,405 & $-0,587$ & $-0,608$ \\
C1 & 1,4541 & 0,462 & $-0,858$ & $-0,448$ \\
C3 & 0,8015 & 0,672 & 0,381 & $-1,411$ \\
C4 & 1,0099 & 0,622 & $-0,018$ & $-1,390$ \\
C5 & 1,000 & 0,632 & 0,000 & $-1,416$ \\
C6 & 1,1663 & 0,532 & $-0,267$ & $-1,088$ \\
\hline
\end{tabular}

Tabel 6. Statistik Deskriptif Keterampilan Berpikir Siswa Tingkat Rendah dan Tinggi

\begin{tabular}{lllll}
\hline Tingkat & $\begin{array}{l}\text { Rata- } \\
\text { rata }\end{array}$ & Variansi & Skewness & Kurtosis \\
\hline LOTS & 3,6576 & 2,738 & $-0,162$ & $-0,928$ \\
HOTS & 3,1762 & 3,404 & 0,026 & $-0,994$ \\
\hline
\end{tabular}

Berdasarkan Tabel 5 dan 6 diperoleh skor skewness dan kurtosis dari masingmasing tingkat keterampilan berpikir berada di antara $\pm 1,96$ yang berarti data berdistribusi normal. Skor rata-rata tertinggi pada Tabel 5 adalah keterampilan berpikir memahami sedangkan skor rata-rata terendah adalah mengaplikasikan. Pada keterampilan berpikir tingkat tinggi siswa dapat dilihat bahwa skor yang paling rendah ada pada mengevaluasi dan paling tinggi ada pada mencipta. Pada Tabel 6 diperoleh bahwa rata-rata skor untuk LOTS sebesar 3,6576 dan skor ini lebih kecil daripada rata-rata skor HOTS sebesar 3,1762. Hal ini dapat disimpulkan bahwa keterampilan berpikir siswa masih berada tingkat rendah meskipun perbedaan rata-rata skor keduanya tidak terlalu besar.

\section{KESIMPULAN DAN SARAN}

Berdasarkan hasil pengembangan perangkat soal tes bentuk pilihan ganda dapat disimpulkan bahwa jumlah soal matematika yang valid, reliable, mempunyai tingkat kesukaran yang baik, daya pembeda yang baik dan semua distraktornya adalah 12 butir soal dari 24 soal yang dibuat. Hasil pengukuran menggunakan soal tersebut diperoleh kesimpulan bahwa keterampilan berpikir siswa masih berada tingkat rendah.

$$
\text { Saran untuk penelitian }
$$

selanjutnya terutama dalam pengembangan bentuk soal tes pilihan ganda adalah soal yang digunakan untuk mengukur HOTS siswa dibuat lebih banyak pada tiap tingkat kemampuan berpikir sehingga setelah dilakukan analisis butir soal tidak menghasilkan jumlah soal yang sedikit.

\section{DAFTAR PUSTAKA}

Alhaddad, I. (2015). Perkembangan Pembelajaran Matematika Masa Kini. Jurnal Matematika dan Pendidikan Matematika, 13-26.

Amelia, M. A. (2016). Analisis Soal Tes Hasil Belajar High Order Thinking Skills (HOTS) Matematika Materi Pecahan untuk Kelas 5 Sekolah Dasar. Jurnal Penelitian (Edisi Khusus PGSD), 123-131.

Fanani, M. Z. (2018). Strategi Pengembangan Soal Higer Order Thinking Skill (HOTS) dalam Kurikulum 2013. Edudeena : Journal of Islamic Religion Education, 57 - 76.

Halimah, S. (2014). Implementasi

Kurikulum 2013 Dalam Pembelajaran Matematika. Fakultas Tarbiyah dan Ilmu Keguruan Jurusan Tadris Matematika, 1 - 17. 
DOI: https://doi.org/10.24127/ajpm.v8i1.1628

Hasratuddin. (2013). Membangun Karakter Melalui Pembelajaran Matematika. Jurnal Paradikma, 130 - 141.

Hidayati, A. U. (2017). Melatih Keterampilan Berpikir Tingkat Tinggi Dalam Pembelajaran Matematika Pada Siswa Sekolah Dasar. Jurnal Pendidikan dan Pendidikan Dasar, 143 - 156.

Kartowagiran. (2012). Penulisan butir soal. Yogyakarta: Universitas Negeri Yogyakarta.

Kurniason, H. T., Sugiatno, \& Hamdani. (2018). Instrumen Tes Untuk Mengukur Kemampuan Berpikir Matematis Tingkat Tinggi SMA. Jurnal Pendidikan dan Pembelajaran, 1 - 12.

Nasional, S. P. (2003). Undang-undang No. 20 Tahun 2003. Departemen Pendidikan Nasional.

Presiden Republik Indonesia. (2013). Peraturan pemerintah nomor 32 tahun 2013 tentang perubahan atas peraturan pemerintah nomor 19 tahun 2005 tentang standar nasional pendidikan. Jakarta: Presiden Republik Indonesia.
Saido, G. M., Siraj, S., Nordin, A. B., \& Al-Amedy, O. S. (2015). Higher order thinking skills among secondary school students in science learning. The Malaysian Online Journal of Educational Science, III(3), 13-20.

Sulaeman, A. (2015). Pengembangan Kurikulum 2013 Dalam Paradigma Pembelajaran Kontemporer. Islamadina, 71 95.

U.S, S. (2015). Peran Berpikir Kreatif Dalam Proses Pembelajaran Matematika. Formatif : Jurnal Ilmiah Pendidikan MIPA, 248 262.

Wicasari, B., \& Ernaningsih, Z. (2016). Analisis Kemampuan Berpikir Siswa Dalam Menyelesaikan Permasalahan Matematika Yang Berorientasi Pada HOTS. Prosiding Seminar Nasional Reforming Pedagogy, (hal. 249 254). 